\title{
Effect of Problem-Solving Strategy on Chemistry Students' Performance in Secondary Schools in Abia State.
}

\author{
Ndukwe Rosecolette Chibuzor (PhD)* \\ Curriculum Studies and Educational Technology, University of Port Harcourt, Nigeria
}

*Corresponding Author: Ndukwe Rosecolette Chibuzor (PhD), Curriculum Studies and Educational Technology, University of Port Harcourt, Nigeria

\begin{abstract}
The study investigated the effect of problem-solving on Chemistry students' performance in secondary schools in Abia State. The design of the study was quasi experimental; pre-test, post-test, control design. The population consists of 622 SS2 Chemistry students. Purposive sampling technique was used to obtain a sample size of 92 senior secondary two (SS2) Chemistry students in intact classes. One researcher developed test instrument- Chemistry Performance Test (CPT) was validated, the reliability was established using the test re-test method. Reliability coefficient of 0.71 was obtained using Pearson's Product Moment Correlation. Two research questions and two hypotheses guided the study. The data obtained was analyzed using mean and standard deviation to answer the research questions and analysis of covariance (ANCOVA) for testing the null hypotheses at 0.05 level of significance. Findings of the study showed that students exposed to problem-solving strategy had a higher mean performance scores than those taught with the conventional lecture method. There were indications though not statistically significant that male students' performance scores were higher in problem-solving strategy group. Consequently, it is recommended that Chemistry teachers should adopt problem-solving strategy in teaching the mole and other quantitative concepts in Chemistry.
\end{abstract}

Key Words: Problem-solving, Strategy, Chemistry performance, Mole.

\section{INTRODUCTION}

All over the world, attention has been focused on science and technology so that there can be social, economic and political development. Chemistry is the bedrock of technological development. Chemistry as a science subject is an essential tool for technological advancement as its concepts have been useful in the interpretation of biological, physical and chemical phenomena in science. The objectives of Chemistry curriculum among others are to acquire basic theoretical and practical knowledge and skills which equips learners to fit into this drive.

Education is aimed at inculcating in the learner appropriate skills to live in and contribute to the development of the society. So Nigeria sees its science education as a means of producing scientists needed for national development. This cannot be achieved without effective teaching. Therefore, effective teaching results in achieving maximally the set objectives using appropriate instructional methods which must be assessed. Generally, in science and Chemistry education in particular, the instructional format provided by the teacher seems to be the medium of effective learning and good teaching helps the learner while poor teaching leads to poor learning and poor performance (Ibe, 2015).

Gongden \& Delmang (2016) reported that the best way of building science and technology knowledge and allied transfer of technology in a nation is to strengthen science education. Therefore, our science education should not be geared towards the production of bookwarm who would have memorized theories and ready to pure them out. Akpoghol, Samba, \& Asemave, (2015) stated that the teaching of science and technology must provide graduates who have practical exposure endowed with critical thinking and can express most of the scientific observations, theories and concepts using the most appropriate scientific language. As at present efforts are still vigorously made to ensure that our science curriculum meets global standards, more so, that national and personal development are directly linked to science and technology education. Gbamanja (1999) stated that the wealth or poverty of a nation depends on the content of the curriculum. The implementation of the curriculum 

State.

lies in the hands of the teacher. No matter how well developed and comprehensive a curriculum is, its success is dependent on the quality of the teachers implementing it. The Federal Republic of Nigeria FRN (2013) while stressing the importance of teacher quality in curriculum implementation noted that no nation's educational system can rise above the quality of her teachers. Teachers are very important determinants of enrolment, retention and essentially performance towards school subjects. Teachers constitute the pivot upon which schooling rotates (Alebiosu \& Bamiro, 2017). The teacher is a consultant, guide, mentor, aspirator, moderator and facilitator (Seiva, 2014). His /her use of innovative instructional strategy stands a higher chance of positively affecting the learner in a subject.

Laboratory experiments and observations in science classes couldn't help the realization of desired outcomes because those activities remain as cookbook activities designed to verify well-established principles and laws (Njoku, 2014). Even in science classes where those activities take place, students are mostly passive. This contradicts today's cognitive theories which view students as active participants of the learning process.

Problem solving is an investigative task whereby the solver explores the solution path to reach the goal from given information. Udo, (2015) described it as a cognitive learning strategy which is aimed at bridging the gap between conceptual understanding the phenomena and the microscopic representation of the phenomena. Hence, the conceptual knowledge of students can be improved using acquits pedagogy and exposing them to problem-solving. Problem solving is an active pedagogy that links with other innovations which inherently supports a discovery based approach to learning. Ndukwe \& Mumuni 2019) suggested that problem-solving is an interactive classroom instruction that helps students to work on difficult projects which they have no clue and helps them to develop critical thinking skills which is beyond memorization of isolated facts and concepts and promotes deep understanding of science. It is a cognitive learning strategy which bridges the gap between the problem state and the solution state.

Despite the various innovations introduced into science teaching, the performance of students still remains low. This is buttressed by the poor performance of students' in the West African Senior School Certificate Examination (WASSCE). Akpoghol, Samba \& Asemave, (2015) supported the idea that students performance in Chemistry is low and attributed the reason for this among other things to the way Chemistry is taught by teachers. Several other reasons have been identified for the under-performance of students in Chemistry. Some of the identified problems according to Obamanu and Nbina (2011) include inadequacy of laboratory and workshop facilities, low morale and poor preparation of teachers, poor funding of science research, passive teaching strategies and lack of problem-solving skills. It is acknowledged that interactive instructional strategies could enhance students' performance in some topics. Could problem-solving strategy improve students' performance in the mole concept in Chemistry.

\subsection{Objectives of the study}

Specifically, the objectives are to:

1. Examine the effects of problem-solving strategy and lecture method on the students' academic performance in mole concept.

2. Compare the effects of problem-solving on the academic performance of male and female students in mole concept.

\subsection{Research Questions}

1. What are the effects of problem-solving strategy and lecture method on the students' academic performance in mole concept?

2. What are the effects of problem-solving strategy on the academic performance of male and female students in mole concept?

\subsection{Hypotheses}

Ho1. There is no significant difference between the mean performance scores of students taught Chemistry concept with problem-solving strategy and those taught using lecture method. 

State.

Ho2. There is no significant difference between the mean performance scores of male and female students taught Chemistry concept with problem-solving strategy.

\section{METHOD}

The design of the study was a pretest, posttest, control group, quasi-experimental design using $2 \times 2$ factorial design.

The population of the study consists of all six hundred and twenty two (622) senior secondary two (SS2) Chemistry students in the ten (10) state owned co-educational secondary schools in Osisioma Ngwa Local Government Area of Abia State, during the 2018/2019 school year.

(Source: Dept. of Planning, Research and Statistics, Aba Educational zone).

The sample size for this study was 185 which were drawn from four co-educational public secondary schools. The schools were selected using purposive sampling technique.

The criteria were;

1) The schools must have qualified Chemistry teacher(s).

2) The school must have a standard laboratory.

The sample size for this study was 92 which were drawn from two co-educational public secondary schools. Two schools were purposively selected from the existing ten (10) co-educational senior secondary schools in Osisioma Ngwa Local Government Area. Secondly, the total number of students in the intact class of each of the schools constituted the sample for this study. Out of the two schools selected one was randomly assigned to experimental group and one for control group. The groups were pre-tested before the treatment and post-tested after the treatment to ascertain the effect of the strategies on students' academic performance however, the environmental condition of the schools had similar characteristics.

The following instrument was used to collect data for the study:

Chemistry Performance Test (CPT). In developing (CPT) references were made to the content of the mole based on the senior secondary two (SS2) Chemistry curriculums.

The instrument used for data collection was Chemistry Performance Test (CPT) developed by the researcher and validated by two experienced Chemistry teachers and two experts in the field of Science Education validated the CPT in terms of ensuring items clarity and removal of ambiguous words that could confuse the students.

The reliability of CPT was determined using the test re-test method and a reliability index of 0.71 was obtained using Pearson's Product Moment Correlation. CPT is made up of fifty (50) multiple choice objective questions with option A-D having one correct option references was made to the content of electrolysis based on the senior secondary two (SS2) Chemistry curriculum.

The researcher administered the instrument directly on the students in the two groups in two main phases: Pre-test and Post-test.

\subsection{Experimental procedure}

Just before the use of the strategies a pretest was administered by the researcher. This enabled the researcher to determine the base line knowledge of the students. Thereafter the Chemistry lesson plans were used to teach the students by the researcher with the different learning strategies for two (2) weeks. The problem solvers were given a description paper on how to solve mole problems, followed by worksheets and cards containing the concept of the mole and definitions then student's volunteers gave feedback on the given questions which were followed by corrective instruction.

Control procedure, in the control group, the pretest was also administered to ascertain students' baseline knowledge. The researcher followed the conventional lecture method using (talk and chalkboard) to teach the students. After the treatment, the instrument known as CPT- were reshuffled and administered as the post-test in each group. The researcher scored the pre-tests and post-tests and generated quantitative data, which were analyzed. 
Effect of Problem-Solving Strategy on Chemistry Students' Performance in Secondary Schools in Abia State.

Research questions were answered using mean and standard deviation and analysis of covariance (ANCOVA) was used to test the hypotheses.

\section{Results}

Research question1: What are the effects of problem-solving strategy and lecture method on the students' academic performance in the mole concept?

Table1. Mean and standard deviation performance scores of students in experimental group 1 (problem solving) and control group (lecture method).

\begin{tabular}{|c|c|c|c|c|c|c|c|}
\hline \multirow[t]{2}{*}{ Group } & \multirow[t]{2}{*}{$\mathrm{n}$} & \multicolumn{2}{|c|}{ Pre-test } & \multicolumn{2}{|c|}{ Pre-test } & \multirow{2}{*}{$\begin{array}{l}\text { Mean } \\
\text { gain }\end{array}$} & \multirow{2}{*}{$\begin{array}{l}\% \text { mean } \\
\text { gain }\end{array}$} \\
\hline & & Mean & SD & Mean & SD & & \\
\hline $\begin{array}{l}\text { Problem-solving } \\
\text { (Exp. 1) }\end{array}$ & 45 & 28.22 & 6.62 & 66.84 & 7.24 & 38.62 & 57.78 \\
\hline $\begin{array}{ll}\begin{array}{l}\text { Lecture } \\
\text { (control) }\end{array} & \text { method }\end{array}$ & 47 & 28.43 & 5.97 & 48.60 & 9.02 & 20.17 & 41.50 \\
\hline
\end{tabular}

The data in table 1 indicates that the two groups were almost at the same level of performance with a mean performance score of 28.43 and standard deviation of 5.97 for control group and 28.22 and standard deviation of 6.62 for the experimental group 1. For the post mean score, the experimental group 1 obtained a higher mean performance score of 66.84 with a standard deviation of 7.24. The control group obtained a mean performance score of 48.60 with a standard deviation of 9.02. The difference in the post-performance mean scores of the two groups was 18.45 in favour of the experimental group 1. The mean gain scores for the two groups were 38.62 and 20.17 for experimental group 1 and control group respectively. This signifies that the experimental group 1 benefited more in the lesson hence, the problem-solving strategy has affected students' performance to a great extent in Chemistry.

Research question2: What are the effects of problem-solving strategy on the academic performance of male and female students in the mole concept?

Table2. Mean scores for male and female students taught electrolysis using problem-solving in (experimental group 1)

\begin{tabular}{|c|c|c|c|c|c|c|c|}
\hline \multirow[t]{2}{*}{ Group } & \multirow[t]{2}{*}{$\mathrm{n}$} & \multicolumn{2}{|c|}{ Pre-test } & \multicolumn{2}{|c|}{ Post-test } & Mean & $\%$ mean \\
\hline & & Mean & SD & Mean & SD & gain & gain \\
\hline Male & 27 & 28.22 & 6.57 & 66.84 & 7.24 & 38.62 & 57.78 \\
\hline Female & 18 & 28.22 & 6.89 & 66.00 & 9.04 & 37.78 & 57.24 \\
\hline
\end{tabular}

Table 2 shows that male and female students in the experimental group I were originally at the same level of performance with a mean performance score of 28.22 and standard deviation 6.57 for the male and mean of 28.22 and standard deviation of 6.89 for the female students. For the post mean score, male students obtained a mean of 66.84 and standard deviation of 7.24. The female students obtained a mean performance scores of 66.00 with standard deviation of 9.04 . The difference in the post-performance mean scores of male and female students is 0.84 in favour of the male. The mean gain scores for the two groups were 38.62 for male students and 37.78 for the female students. The percentage mean gain scores for the two groups were 57.78 and 57.24 for males and females respectively. This signifies that the male students benefited more in the lesson. Hence problem solving strategy has more effect on the performance of male students than female students.

Hypothesis 1: There is no significant difference between the mean performance scores of students' taught Chemistry concept with problem solving strategy and those taught using lecture method.

Table3. Analysis of covariance (ANCOVA) of post-test scores. Classified by treatment using pre-test as covariates.

\begin{tabular}{|l|l|l|l|l|l|l|}
\hline Source of variation & $\begin{array}{l}\text { Type III } \\
\text { sum of squares }\end{array}$ & Df & Mean square & F & Sig & Partial Eta squared \\
\hline Corrected model & 9874.185 & 4 & 2468.546 & 56.033 & .000 & .720 \\
\hline Intercept & 5288.224 & 1 & 5288.224 & 120.037 & .000 & .580 \\
\hline Pretest & 2196.432 & 1 & 2196.432 & 49.857 & .000 & .364 \\
\hline Group/treatment & 7397.989 & 1 & 7397.989 & 167.927 & .015 & .659 \\
\hline
\end{tabular}


Effect of Problem-Solving Strategy on Chemistry Students' Performance in Secondary Schools in Abia State.

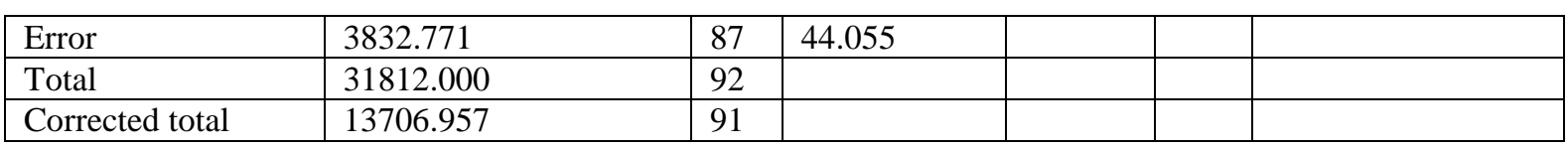

Remark $=$ Significant

The hypothesis was tested at 0.05 level of significance using a two way (2x2) analysis of covariance (ANCOVA), the pre-test scores are used as covariates to the post-test scores.

The table 3 shows that the significant level of 0.015 is lower than 0.05 the hypothesis is therefore rejected meaning that problem solving is a significant factor in the students overall performance in their mean performance scores in Chemistry.

Hypothesis 2: There is no significant difference between the mean performance scores of male and female students' taught Chemistry concept with problem solving strategy.

Table4. Analysis of covariance (ANCOVA) of post-test scores, classified by treatment and gender using pre-test as covariates.

\begin{tabular}{|l|l|l|l|l|l|l|}
\hline Source of variation & $\begin{array}{l}\text { Type III } \\
\text { sum of squares }\end{array}$ & df & Mean square & F & Sig & $\begin{array}{l}\text { Partial } \\
\text { squared }\end{array}$ \\
\hline Corrected model & 9874.185 & 4 & 2468.546 & 56.033 & .000 & .706 \\
\hline Intercept & 5288.224 & 1 & 5288.224 & 120.037 & .000 & .568 \\
\hline Pretest & 2196.432 & 1 & 2196.432 & 49.857 & .000 & .352 \\
\hline Group/treatment & 7397.989 & 1 & 7397.989 & 167.927 & .015 & .642 \\
\hline Gender & 16.329 & 1 & 16.329 & .371 & .544 & .004 \\
\hline Group * Gender & 6.625 & 1 & 6.625 & .150 & .699 & .002 \\
\hline Error & 3832.771 & 87 & 44.055 & & & \\
\hline Total & 31812.000 & 92 & & & & \\
\hline Corrected total & 13706.957 & 91 & & & & \\
\hline
\end{tabular}

Remark $=$ Not Significant

The table 4 shows that the significant level of 0.544 is higher than 0.05 , the hypothesis was therefore accepted meaning that there was no significant difference between the performance of male and female students taught Chemistry concept with problem-solving.

\section{Discussion OF FINDINGS}

The results in Tables 1 and 3 shows that the students who were taught through the Problem-Solving instructional strategy performed statistically better in the Problem-Solving compared to those that were taught through the lecture method. This implies that Problem-Solving instructional strategy is more effective in enhancing students' performance. The result is in conformity with the findings of (Alabi \& Lasisi 2016; Jegede \& Fatoke 2014; Ndukwe \& Nwanekezi 2019) convincingly showed that the problem solving approach proved to be more effective and reliable method of teaching than the conventional lecture method. Other empirical studies which gave positive effects of problem-solving on achievement in other science subjects includes Ishaku (2015), Adebola and Saraki (2016). Udo (2015) reported that problem solving helped the learners to think through the various steps to the solution of the problem at hand. Olajengbesi and Aluko (2014) investigated the influence of concept maps and problem solving instructional strategies on secondary school learning outcomes in Chemistry, reported that students' taught with problem solving strategy performed significantly better than those taught with concept mapping.

The results in Tables 2 and 4, shows that male students performed better than their female counterparts, although the result was not statistically significant. The result agreed with the findings of Jegede and Fatoke (2014) who reported that gender is not a perfect predictor as far as Chemistry achievement is concerned, whether students are taught using problem-solving or traditional method. This also agreed with the findings of Ishaku (2015) and Akpoghol (2015) who contends that gender is not a relevant factor to be associated with school achievement.

\section{CONCLUSiON}


The study concluded that the problem-solving strategy is an effective instructional strategy when compared with the conventional lecture method in the learning of the mole concept in Chemistry. It is an effective instructional strategy for promoting the ability of students to solve problems as the posttest scores revealed. It also helped teachers to expose students on the ways scientists works. The male students' academic performance scores were higher than the female students' scores in problemsolving strategy, the difference were not statistically significant as revealed by the findings. Chemistry teachers should adopt activity based instructional strategy such as problem-solving, in the teaching and learning of the mole concept in Chemistry in Abia State for it is an effective method of instruction which improved students' academic performance.

\section{REFERENCES}

[1] Adesoji, F. A. (2017). Students' ability level and effectiveness of problem-solving. Retrieved on $16^{\text {th }}$ April, 2018 from www.tandfoniline.com/du/abs/101080/09718923

[2] Adebola, S. I \& Saraki, I. A (2016). A problem solving model as a strategy for improving secondary students' achievement and retention in further Mathematics. ARPN Jounal of science and technology. 2(2), 17-25.

[3] Akpoghol, T. V, Samba, R. M. O \& Asemave, K. (2015). Effect of problem solving strategy on students' achievement and retention in secondary school Chemistry. Journal of applied developmental psychology. 12(6). 71-82.Retrieved on $4^{\text {th }}$ April 2018 from https://www.reseachgate.net/ public.pdf.

[4] Akpoghol, T. V., Samba, R. M. O \& Asemave, K. (2015). Effect of problem solving strategy on achievement and retention amongst secondary school students. Journal of applied developmental psychology. 12(6), 71-81. Retrieved on $4^{\text {th }}$ April 2018 from ac.edu.pk/jeve/unicles/53040.pdf.

[5] Alabi, T. O. \& Lasisi, N. (2016). Effects of guided discovery and Problem solving instructional strategy on achievement of secondary school student in Niger State. Journal of science technology and education (JOSTE). 3(4), 75-78.

[6] Alebiosu, K. A. \& Bamiro, O. A. (2017). Teaching Chemistry as activity oriented: Teachers' knowledge and practice of science activities. Nigerian journal of curriculum studies. 18(2), 8-19).

[7] Federal Republic of Nigeria. (2013). National policy on education $5^{\text {th }}$ edition. Lagos. NERDC. Press

[8] Gbamanja, S. P. T., (1999). Modern methods in science education in Africa. Port Harcourt: Paragraphics.

[9] Gongden, E. J. \& Delmang, T. K. (2016). The efficacy of concept mapping instructional strategy in remedying students problem-solving difficulties $\mathrm{n}$ stoichiometry. An international multi- dissciplinary journal, Ethiopia. 10(2). 144-157.

[10] Ibe, H. N. (2015). Effects of guided discovery-inquiry and expository teaching methods on senior secondary school students' performance in biology in Imo state. Journal of educational research and behavioural sciences. 2 (4). 51-57.

[11] Ishaku, C. (2015). Effects of problem-solving and discussion teaching methods on students' achievement in genetics. Retrieved $12^{\text {th }}$ April 2018 fromhttp:/ijedit.dec.uwi.edu//viewarticle.php? id=677 \& I about $=$ html.

[12] Jegede, S. A. \& Fatoke, A. O. (2014). The effects of problem-solving instructional strategy, three modes of instruction and gender on learning outcomes in Chemistry. Journal of education on practice. 5(23). 179184.

[13] LiBong, A. Y \& Lee, T. T. (2016). Form four students' misconceptions in electrolysis of molten compounds and aqueous solutions. Asian-pacific forum on science learning and teaching. American research review. 17(8). 23-30.

[14] Ndukwe, R. C. \& Mumuni, A. A. O. (2019). Effects of instructional strategies on Chemistry students' retention in secondary schools in Osisioma Ngwa local government Area, Abia State. British international journal of education and social sciences. 6(7). 45-53.

[15] Ndukwe, R. C. \& Nwanekezi, A. U. (2019). Effects of instructional strategies on Chemistry students' performance in secondary schools in Osisioma Ngwa local government Area, Abia State. Trends in educational studies (TRES). 11(3).164 - 175.

[16] Njoku, Z. C. (2014). Fostering the application of science education research findings in Nigerian classroom. Strategies and needs for teachers' professional development. In M.A.G. Akale (Ed) $45^{\text {th }}$ annual conference proceeding science teachers' association Nigeria. (217- 222). Ibadan: HEB (Nig) PLC. 

State.

[17] Obomanu, B. J. \&Nbina, J. B. (2011). Assessment of the effects of problem solving instructional strategies on students' achievement and retention in Chemistry with respect to location in rivers state. World journal of education. 1(2). 74-79.

[18] Olajemgbesi, A. \& Aluko, K. O. (2014). Effects of concept mapping and problem-solving instructional strategies on secondary school learning outcomes in Chemistry. Journal of American research review. 2(1). 162-176.

[19] Seiva, U. (2014). Strategies for science teaching and learning. Retrieved $12^{\text {th }}$ April 2018 from http://www. scienceuniverseedu.cu/school/support/strategy html

[20] Udo, M. E. (2015). Effects of problem-solving, guided discovery and expository teaching strategies on students' performance in redox reactions. An international multi- disciplinary journal; Ethiopia 5(4), 231-241.

[21] West African Examination Council (2015). The West African Senior School Certificate Examination May/June 2015 Chief examiners reports (Nigeria). Lagos. 157-196.

Citation: Ndukwe Rosecolette Chibuzor (PhD). "Effect of Problem-Solving Strategy on Chemistry Students" Performance in Secondary Schools in Abia State." International Journal of Humanities Social Sciences and Education (IJHSSE), vol 8, no. 7, 2021, pp. 226-232. doi: https://doi.org/10.20431/2349-0381.0807025.

Copyright: (C) 2021 Authors. This is an open-access article distributed under the terms of the Creative Commons Attribution License, which permits unrestricted use, distribution, and reproduction in any medium, provided the original author and source are credited. 